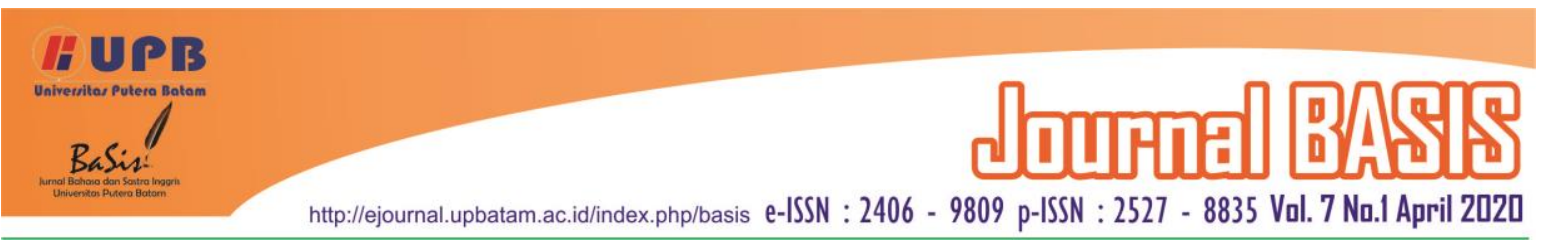

\title{
THE NURSING STUDENTS' NEED OF LEARNING MEDIA FOR LEARNING ENGLISH
}

\author{
Desi Rochmawati \\ Politeknik Kesehatan Kemenkes Yogyakarta (Polkesyo), Yogyakarta, Indonesia \\ desi_rochmawati@yahoo.co.id
}

\begin{abstract}
English language is frequently taught in Indonesian vocational college such as in Nursing Department. It is such a challenge for the students and the lecturer as well due to the tight schedule. The students need more exposures in English language, but the English course so far is only taught conventionally in the classroom once in a week for 2 semesters. The students need to fulfill certain competence in English in effective ways, one of the competence is English speaking skill. Learning speaking needs more effective methods. The methods could be in the form of the media used in teaching learning process. Besides, English speaking skill was so urgent for the students both in academic affair and professionalism. This study, therefore, observes the students' need of learning media for learning English speaking. This was a qualitative research by conducting a syllabus investigation, interview, and questionnaire to collect the qualitative research data. The quantitative data was also conducted through delivering questionnaires to add the meaning of the qualitative data. This study revealed the kinds of learning media that the students need in learning English speaking skills that would also help them easily get the English courses exposures. The appropriate learning media for learning English speaking was a mobile learning media which has portability and high connectivity. It was a kind digital learning media that can be accessed at anytime and anywhere, installed in their smartphones which consisted of some speaking activities and their supporting activities.
\end{abstract}

Keywords: English speaking; high connectivity; learning media; nursing students need; portability

\section{INTRODUCTION}

Nursing students are supposed to have English proficiency and speaking skill is the main target for the students in learning English. As the researcher knows that active skill is demanded to support their professionalism and for the academic needs. It is because speaking skill is very important for communication. Speaking skill is used in many different purposes and different situations. As seen in Richards \& Renandya (2002), they state that most of the world's language learners study English in order to develop their speaking proficiency. It is a very complex task both in foreign and second language. To begin with, speaking is used for many different purposes, and each purpose involves different skills like may be to make social contact with people, to engage with friends or relatives, to seek or express opinions, to persuade someone about something, or to clarify information. Sometimes English is used to get things, to describe things, to complain about people's behavior, to make polite requests. 
English proficiency skill is also used to support one the program in Politeknik Kesehatan Yogyakarta (Polkesyo) that is 'Mendunia' (Globalized). Globalized means that Polkesyo will collaborate with univeristies or vocational collages from abroad.The implementation of the program will be various involving students and lecturers. Some parts of the program are students exchange, lecturers exchange, international conference, campus visit, internship, and also scientific research. All of these must need English competence to strongly support the implementation of the program.

Nursing students in nursing department of Polkesyo have a lot practical activities. They have very tight schedule for other subjects related with the concentration of the program. They get very limited of English language exposure. The students get English language exposure only in English class which is only once a week. It means that they need more access to English language learning. They need a kind of English learning media that exactly appropriate with their needs despite of the conventional method they use to get.

This study examines the nursing students need in learning media to get more acces in English language. The focus of this research are identifying the kind of learning media as the nursing students need to accommodate their activities as student in nursing program and as a language learner.

\section{LITERATURE REVIEW}

English language for nursing program is an English for Specific Purpose (ESP) which is used for particular domain. Carter \& Nunan (2001) add that ESP may be designed for specific disciplines or professions that ESP lecturer needs to be responsible for the specific subject knowledge, which leads to classroom interaction and teaching method that can be quite different from general English. Evans (1998) also states that students in certain program need English to support their educational and professional needs like to understand textbooks or articles which were written in English, to write case reports, or to participate in group discussion. In this research, I want to observe the students need of learning media which is appropriate with them. Bosher (2006) as cited in Paltridge and Starfield (2013) states that one part in English for Specific Purpose (ESP) field is English for Nursing. It focuses on the way nurses use English both in professional setting as well as in nursing education. In nursing program, the students are demanded to be able to communicate using international language, make a report of nursing treatment, understand the report and the nursing treatment, and also do a presentation. Richards (2008) adds the mastery of speaking skills in English is a priority for both second or foreign language learners. Brown (2000) states that from communicative, pragmatic view of the language classroom, listening and speaking skills are closely intertwined. The interaction between the two language skills applies especially to conversation. Richards (2008) states that the mastery of speaking skills in English is a priority for many second language learners or foreign language learners because consequently, the learners evaluate their success in 
learning a language by looking at their spoken proficiency. Richards and Renandya (2002) also suggests one form of speaking activities. He suggests simple conversation. Goh \& Burns (2012) state that there are four categories of core speaking skills that learners need to develop; pronunciation, speech function, interaction management, and discourse organization.

Active learning is instructional strategies include a wide range of activities that shares the common element of 'involving students in doing things and thinking about the things they are doing (Bonwell \& Eison 1991). Active learning instructional strategies can be created and used to engage the students in; a) thinking critically and creatively, b) speaking with a partner, in a small group, or with the entire class, c) expressing ideas through writing, d) exploring personal attitudes and values, e) giving and receiving feedback, and f) reflecting upon the learning process. Active learning strategies can be completed by students either in class or out of class, it can be done by students working either as individuals or in group, and it also can be done either with or without the use of technology (Eison, 2010). Previous research by Al-Rahmi \& Othman (2013) showed the use of digital media in teaching learning process would help to increase the students' motivation through collaborative learning. Another research discussing learning media was a research by Fauza, et al. (2018) which showed that students speaking skill and motivation could be enhaced by using Puppet media.

The development of communication technology is in accordance with the development of mobile devices such as smart phones or tablet. Mobile learning or m-learning is a type of e-learning that delivers educational contents and learning support materials through wireless communication devices. Traxler as cited in Cabanban (2013) describes mobile learning as a personalized, connected and interactive use of handled computers in classrooms. M-learning is a combination of the implementation of mobile connectivity and electronic learning. Another concept of m-learning as stated by Kukulska-Hulme \& Traxler (2005) is that learners can do educational activities outside the classroom anytime and anywhere since the mobile devices which are used to do m-learning are categorized as portable, lightweight devices that are small enough to fit in the palm of one's hand. Miangah \& Nezarat (2012) state that learning through mobile phone or $\mathrm{m}$ learning provides the learners with the opportunity to learn when they are in public places or outside the classroom. Mobile device has two main characteristics which contribute to the use of m-learning. The characteristics are portability and connectivity. Connectivity is the capability of being connected and communicated with the learning website using wireless network of the device to access learning material. Portability enables learners to move mobile devices and bring learning materials. Huang et al (2012) as cited in Viberg and Gronlund (2012) also add that "mobile technologies provide many advantages; flexibility, low cost, small size and user-friendliness, researcher exploring how to use mobile technology to support language learning. The disadvantages of m-learning as Miangah 
\& Nezarat (2012) state that mobile devices have constraints such as small screen, reading difficulty on small screen, data storage and multimedia limitations like limitation on size of the application which cause the application does not work well or slowly in operating.

Miangah \& Nezaret (2012) claim that MALL deals with the use of mobile technology in language learning. The students do not only learn language in the classroom but they can learn English through the application installed in their gadget (smart phone or tablet). Pachler, Bachmair and Cook (2010) as cited in AbuSa'aleek (2014) defines MALL as "the processed of coming to know and being able to operate successfully in, and across, new and ever changing contexts and learning spaces with an emphasis on understanding and knowing how to utilize our everyday life-worlds as learning spaces." Other definition of MALL is from Wood (2003), he states that "the term of mobile learning refers to the use of mobile and handled IT devices, such as PDAs, mobile phones, laptops and tablet PCs, in teaching and learning (AbuSa'aleek, 2014).

\section{RESEARCH METHOD}

The steps taken in conducting this research were research and information collecting including literature review, and survey. The survey was conducted by investigating syllabus, interview and questionnaires. The need survey was conducted by interviewing English lecturer and the students and also distributing questionnaire to the students. The researcher also investigated the curriculum and syllabus to get knowledge for the product development.

In conducting need analysis, the researcher interviewed nursing student in semester 4 and English lecturer of Poltekkes Yogyakarta, conduct observation, and distribute questionnaire to the target learners. Thus the setting was in Poltekkes Yogya. I used two kinds of instruments to obtain the data. Those were questionnaires and interview. Borg and Gall (2003) states that questionnaires are documents that ask the same questions of all the samples. Respondents record a written or typed response to each questionnaire item and also possible to fill out the questionnaire at their convenience (p. 221). Interview was also conducted to gain more detail information related to the questionnaires. I conducted interview to the research participants and respondents. The interview was still similar with questionnaire items. The first interview was conducted with the nursing students and English lecturer that were about the students need, students' characteristics and teaching method (need analysis step).The need analysis was performed by sharing questionnaire, doing interview with the students and the lecturers and also dong class observation.

Tabel 1. The Stages, Data, Participants and Instruments

\begin{tabular}{|c|c|c|c|}
\hline Steps & Information Needed & Participants & $\begin{array}{l}\text { Instrume } \\
\text { nts }\end{array}$ \\
\hline $\begin{array}{l}\text { Researc } \\
\text { h and } \\
\text { Informa } \\
\text { tion } \\
\text { Analysis }\end{array}$ & $\begin{array}{l}\text { - The previous method } \\
\text { and tools in English } \\
\text { lesson } \\
\text { - The students' real } \\
\text { need } \\
\text { - The students' } \\
\text { difficulties in learning } \\
\text { English related with } \\
\text { understanding the } \\
\text { materials } \\
\text { - The students' obstacle } \\
\text { in learning English } \\
\text { related with time } \\
\text { - The characteristic of }\end{array}$ & $\begin{array}{l}\text { - Nursing } \\
\text { students of } \\
\text { Poltekks } \\
\text { Yogyakarta } \\
\text { - English } \\
\text { Lecturers of } \\
\text { Poltekkes } \\
\text { Yogyakarta }\end{array}$ & $\begin{array}{l}\text { Question } \\
\text { naire } \\
\text { Interview }\end{array}$ \\
\hline
\end{tabular}




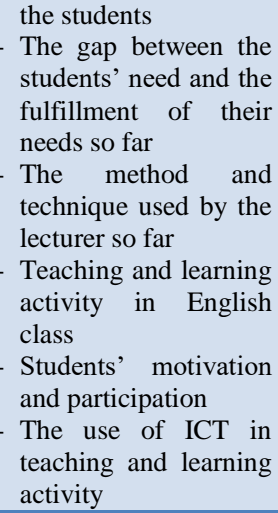

I used two kinds of questionnaire; close ended questions and open ended questions to get some information. In research and information collecting step, the questionnaires were distributed to nursing students of Poltekkes Yogyakarta to gain information related with students' needs, interests, and characteristics. The questionnaires were written in bahasa Indonesia to get accurate data from the respondents. The working concept for need analysis questionnaires can be seen in Appendix 1.

In this research, I conducted interview to gain more detail information from the questionnaires. Borg (1983) states that interview permits the researcher to follow-up leads and thus obtain more data and greater clarity. In interview, the obtained data were deeper than the other method of collecting research data (p.436). So, I conducted interview to gain more detail information from the respondents. The interview was conducted in research and information collecting step. In research and information collecting, I interviewed English lecturer from Poltekkes Yogyakarta and a nursing student of the same Poltekkes. The interview was conducted to gain more detail information which had been obtained from the questionnaire either in close-ended questions or open-ended questions. The result of sharing the questionnaires was analyzed statistically. The first step was recapitulating the data in the form of table and the second step was calculating the data using percentage. The formula for getting the percentage is seen in the following part;

\section{$\frac{n}{N} X 100 \%$}

Notes :

$\mathrm{n}$ : The total number of the participants who choose certain answer $\mathrm{N}$ : the total number of the participants

Previously, the table format for recapitulating the participants as the result from the questionnaire is seen as the following table:

Tabel 2. The Result of the Need Analysis Questionnaire

\begin{tabular}{|l|l|l|l|}
\hline Question & Response & Number & Percentage \\
\hline & & & \\
\hline
\end{tabular}

The data from the questionnaires were in the form of likert scale, so the researcher needed to a system for scoring the data. Creswell (2012) suggests that scoring data means that the researcher assigns a numeric score or value to each response category for each question on the questionnaires. The scoring data was in the form of Likert Scale proposed by Creswell (2012). There are five agreements are applied as follows: Strongly agree $=5$, Agree $=4$, Undecided disagree $\quad=1$ 


\section{RESULT AND DISCUSSION}

The data was obtained by investigating the syllabus English lesson syllabus for Nursing Program, interviewing the English lesson lecturers, and distributing pre-design questionnaire to the targeted learners.

4.1 Syllabus Investigation

The first concern of theoretical model was the syllabus investigation because in determining the content for the learning model must be appropriate with the English lesson syllabus in Nursing Program. There were four main objectives of English subject in Nursing Program; 1) students should be able to communicate in English, 2) students should be able to write nursing education in English, 3) students should be able to understand oral text related with issues and nursing reports, 4) students should be able to present in English (syllabusdoc). Based on the four objectives above, it was obviously mentioned that speaking ability was the main focus of English subject in Nursing Program. In order to have a good speaking skill, there are four categories of core speaking skills that the students need to develop; pronunciation, speech function, interaction management, and discourse organization (Goh \& Burns, 2012). This is the reason I would like to develop a learning media which can be able to help the students in speaking practices.

\subsection{Result of Interview}

In process of getting the information about the students' need, interview with one of the lecturers of English course and one of the nursing students were conducted to collect data. The data needed from the interviews were learning objectives, students' characteristic, teaching and learning process, teaching technique, and teaching media.

In the interview with the lecturer, she implied that the objective of English lesson in Nursing Program focused on students' ability in speaking. She claimed that the students in Nursing Program had good competence in English, they also had enthusiasm in learning English (App4). In the classroom, most of the students were active and enthusiastic in taking part in the teaching learning process. From the interview, it can be seen that speaking ability was so important for the nursing students. In the classroom, the students practicing debate, discussion, and presentation. The material for those speaking activities must be issues related with nursing area. But, even though they had good competence in English, they still need more practice in medical vocabulary. In the interview, the lecturer also mentioned that most of the students had smart phones with Android operating system and the lecturers as well.

The second interview was with one of the nursing students. Here in the interview, the student said that most of the students had already used smart phones or tablets. The student told that in students' opinion English is very important because as students they had goals such as continuing their study in abroad university, facing globalization era where they should compete with human resources from many countries, communicating with their patients, and also supporting their professionalism as professional nurse. In the interview the student also added that generally students still had difficulties in English language. 
The difficulties were the ability in speaking up with others, whereas from the previous interview with the lecturer, she told that in English lesson she was responsible for certain material in English that was speaking material like debate, seminar, and discussion. It means that in fact, the students had already got speaking material but they thought that they still need to improve their speaking ability. Besides speaking ability, vocabulary mastery was one thing that should be considered in learning English.

In English class, not all of the students were enthusiastic with English lesson. Some of them were not really enthusiastic because they already thought English was difficult and they lacked of confidence in speaking (App6). They needed more practice in speaking actually, but their schedule for other subjects and nursing laboratory practices had taken their time. They were so busy so that English was not their priority. The finding in the interview was that actually the students wanted to have ability in speaking English. It was in accordance with the objectives of English subject as written in the syllabus that the English lesson aimed at enhancing the students' communication skill using English language. In the interview, the student claimed that they need balance opportunity among others, they wanted to have the same chances to practice their speaking because sometimes they did not have similar opportunity in practicing their English speaking in the classroom.

The student also added that the other difficulties in learning English were materials related with listening, grammar, and pronunciation. They thought that in listening practice, the speaker's pronunciation was not clear so that they cannot catch the meaning of the listening text. Grammar material was also difficult for most of the students. One other thing that was also difficult for the nursing students was about pronunciation. Sometimes the students pronounce certain medical terms with wrong pronunciation.

Another finding of this research was the fact that students needed learning tool or learning media which is flexible so that they can access the English material anytime and anywhere. It was due to their hectic schedule. The students could only learn English in the classroom and nothing else. It was implied that the students rarely deal with English materials but they were supposed to be able to communicate in English language. In the classroom, the media for learning English were books, handouts, power point slides, and copy of exercises. Technology had been used in the process of teaching and learning but only in form of email for sending or submitting English material and also assignments from the lecturer to the students and vice versa. Those media were not practical, whereas the students needed a learning tool that supported them in practicing English, especially speaking practice (Арp6).

The students in Nursing Program, according to the English subject syllabus, were supposed to be able to communicate using English language either for their academic affairs or their professionalism. The students, therefore, needed a learning tool which supported the nursing students' need, a learning tool which is mobile, flexible and can be used not only in the classroom, but also outside the classroom. In other words, the students 
needs a portable alternative learning tool which enables the students to move mobile devices and bring the learning material even in the middle of their hectic schedules in Nursing Program. In chapter II of this study has been discussed the characteristics of mobile learning which may support the nursing students' need, those are; portability and connectivity (Miangah \& Nezaret, 2012) and also equitable, flexible, simple, perceptible, and tolerance for error (Elias, 2012).

4.3 Questionnaire Result on Students' Need

Questionnaires were distributed among the nursing students of Poltekkes Yogyakarta to gain the information on the students' need from their points of view. The questionnaires were distributed to 44 students in Regular Class in Nursing Department. The concepts in the need analysis are based on the current concepts of need analysis by Dudley-Evan and St John (1998) and Oral Communication Skill by Brown (2000). The following tables present the options of each question or statement and also the result of the need analysis questionnaire;

Table 3. The Students' Need and Opportunity in Learning English

\begin{tabular}{|c|c|c|c|c|}
\hline No. & $\begin{array}{l}\text { Questions } \\
\text { or statements }\end{array}$ & Answers & Number & $\begin{array}{l}\text { Percent } \\
\text { age }\end{array}$ \\
\hline 1. & $\begin{array}{l}\text { So far, English } \\
\text { lesson is ... }\end{array}$ & $\begin{array}{l}\text { a. very easy to } \\
\text { understand } \\
\text { b. easy to } \\
\text { understand } \\
\text { c. average } \\
\text { d. difficult to } \\
\text { understand } \\
\text { e. very difficult to } \\
\text { understand }\end{array}$ & $\begin{array}{l}0 \\
\\
14 \\
22 \\
7 \\
1\end{array}$ & $\begin{array}{l}0 \% \\
31.8 \% \\
50 \% \\
15.9 \% \\
2.3 \%\end{array}$ \\
\hline 2. & $\begin{array}{l}\text { In my opinion, } \\
\text { learning English } \\
\text { in an active way } \\
\text { is ... }\end{array}$ & $\begin{array}{l}\text { a. very necessary } \\
\text { b. necessary } \\
\text { c. uncertain } \\
\text { d. unnecessary } \\
\text { e. very }\end{array}$ & $\begin{array}{l}29 \\
15 \\
0 \\
0 \\
0\end{array}$ & $\begin{array}{l}65.6 \% \\
34.1 \% \\
0 \% \\
0 \% \\
0 \%\end{array}$ \\
\hline
\end{tabular}

\begin{tabular}{|l|l|l|l|l|}
\hline & & unnecessary & & \\
\hline 3. & Opportunity to & a. strongly enough & 3 & $6.8 \%$ \\
& learn English so & b. enough & 27 & $61.4 \%$ \\
& far is ... & c. uncertain & 3 & $6.8 \%$ \\
& & d. less & 9 & $20.4 \%$ \\
& & e. very less & 2 & $4.5 \%$ \\
\hline
\end{tabular}

Based on the table above, part of the students $(50 \%)$ considered English lesson is average, they felt that learning English so far was neither difficult to understand nor easy to understand. However, English lesson so far was easy to understand for more than one third of the students $(34.1 \%)$, a little part of the students $(15.9 \%)$ considered that English lesson was difficult to understand, whereas the rest of the student $(2.3 \%)$ considered English lesson was very difficult to understand. Learning English in an active way was very necessary for most of the students $(65.6 \%)$ and necessary for the rest of the students $(34.1 \%)$. Most of the students also claimed that the opportunity for learning English was enough (61.4\%), strongly enough $(6.8 \%)$, and uncertain $(6.8 \%)$. In the other hand, $20.4 \%$ students claimed that the opportunity was less, and $4.5 \%$ of them claimed it was very less.

The result above generally shows that English lesson so far was neither difficult nor easy to understand for most of the nursing students. Positively, the students thought that learning English in active way was very important for them and so far, most of them thought they got enough opportunity in learning English. But, there were some students still thought that they still needed more opportunity in learning English.

Table 4. The Use of Technology in Learning Media

\begin{tabular}{|l|l|l|l|l|}
\hline No. & Questions and & Answers & Num & Perc \\
\hline
\end{tabular}




\begin{tabular}{|c|c|c|c|c|}
\hline & statements & & ber & $\begin{array}{l}\text { entag } \\
\mathrm{e}\end{array}$ \\
\hline 4 & $\begin{array}{l}\text { Technology has } \\
\text { been used in } \\
\text { English lesson } \\
\text { in nursing } \\
\text { department }\end{array}$ & $\begin{array}{l}\text { a. strongly agree } \\
\text { b. agree } \\
\text { c. doubt } \\
\text { d. disagree } \\
\text { e. strongly } \\
\text { disagree }\end{array}$ & $\begin{array}{l}3 \\
24 \\
15 \\
2 \\
0\end{array}$ & $\begin{array}{l}6.8 \% \\
54.5 \\
\% \\
34.1 \\
\% \\
4.5 \% \\
0 \%\end{array}$ \\
\hline 5 & $\begin{array}{l}\text { Learning } \\
\text { speaking } \\
\text { material by } \\
\text { using mobile } \\
\text { devices which } \\
\text { can be accessed } \\
\text { anytime and } \\
\text { anywhere helps } \\
\text { students remain } \\
\text { to have English } \\
\text { lesson. }\end{array}$ & $\begin{array}{l}\text { a. strongly agree } \\
\text { b. agree } \\
\text { c. doubt } \\
\text { d. disagree } \\
\text { e. strongly } \\
\text { disagree }\end{array}$ & $\begin{array}{l}28 \\
18 \\
0 \\
0 \\
0\end{array}$ & $\begin{array}{l}63.6 \\
\% \\
40.9 \\
\% \\
0 \% \\
0 \% \\
0 \%\end{array}$ \\
\hline 6 & $\begin{array}{l}\text { Mobile devices } \\
\text { (smart } \\
\text { phones/tablets) } \\
\text { should contain } \\
\text { application } \\
\text { which enlarge } \\
\text { knowledge such } \\
\text { as application to } \\
\text { enhance } \\
\text { speaking ability. }\end{array}$ & $\begin{array}{l}\text { a. strongly agree } \\
\text { b. agree } \\
\text { c. doubt } \\
\text { d. disagree } \\
\text { e. strongly } \\
\text { disagree }\end{array}$ & $\begin{array}{l}21 \\
23 \\
0 \\
0 \\
0\end{array}$ & $\begin{array}{l}47.7 \\
\% \\
52.3 \\
\% \\
0 \% \\
0 \% \\
0 \%\end{array}$ \\
\hline
\end{tabular}

In learning English so far, $6.8 \%$ of the students strongly agreed that technology had been used in English lesson in the classroom and so do the $54.5 \%$ of them, they agreed that technology has been used in teaching learning process. In the other hand $34.1 \%$ of the students doubted and $4.5 \%$ of the students did not agree that technology had been used in teaching learning process. Most of the students strongly agreed $(63.6 \%)$ and agreed $(40.9 \%)$ if there were learning media which can be accessed anytime and anywhere helped them in learning speaking. The students also strongly agreed (47.7\%) and agreed $(52.3 \%)$ that mobile devices with Android operating system should contain application which can enlarge their knowledge and ability such as speaking ability.

The result above shows that learning media which has used technology has not been seriously used as a learning tool. It also shows that the students need a learning media which is simple and technological based that can be accessed anytime and anywhere. The students also thought that due to the increases of mobile devices or gadget in publics, the mobile devices should contain educative application such as application to enhance speaking ability.

Table 5. Language Skills and Components

\begin{tabular}{|c|c|c|c|c|}
\hline No. & $\begin{array}{l}\text { Question or } \\
\text { statements }\end{array}$ & Answers & Number & Percentage \\
\hline $\begin{array}{l}7 \\
.\end{array}$ & $\begin{array}{l}\text { Learning speaking } \\
\text { correctly and } \\
\text { fluently needs to } \\
\text { be practiced. }\end{array}$ & $\begin{array}{l}\text { a. strongly agree } \\
\text { b. agree } \\
\text { c. uncertain } \\
\text { d. disagree } \\
\text { e. strongly } \\
\text { disagree }\end{array}$ & $\begin{array}{l}25 \\
19 \\
0 \\
0 \\
0\end{array}$ & $\begin{array}{l}56.8 \% \\
43.2 \% \\
0 \% \\
0 \% \\
0 \%\end{array}$ \\
\hline 8 & $\begin{array}{l}\text { Speaking skill is } \\
\text { mostly needed by } \\
\text { nursing students. }\end{array}$ & $\begin{array}{l}\text { a. strongly agree } \\
\text { b. agree } \\
\text { c. doubt } \\
\text { d. disagree } \\
\text { e. strongly } \\
\text { disagree }\end{array}$ & $\begin{array}{l}18 \\
26 \\
0 \\
0 \\
0\end{array}$ & $\begin{array}{l}40.9 \% \\
59 \% \\
0 \% \\
0 \% \\
0 \%\end{array}$ \\
\hline $\begin{array}{l}9 \\
.\end{array}$ & $\begin{array}{l}\text { Learning } \\
\text { vocabulary related } \\
\text { with nursing area } \\
\text { is helpful in } \\
\text { enhancing } \\
\text { vocabulary } \\
\text { mastery }\end{array}$ & $\begin{array}{l}\text { a. strongly agree } \\
\text { b. agree } \\
\text { c. doubt } \\
\text { d. disagree } \\
\text { e. strongly } \\
\text { disagree }\end{array}$ & $\begin{array}{l}16 \\
28 \\
0 \\
0 \\
0\end{array}$ & $\begin{array}{l}36.4 \% \\
63.6 \% \\
0 \% \\
0 \% \\
0 \%\end{array}$ \\
\hline 10. & $\begin{array}{l}\text { Learning language } \\
\text { expression related } \\
\text { with nurse's job is } \\
\text { helpful to enhance } \\
\text { students' speaking } \\
\text { ability }\end{array}$ & $\begin{array}{l}\text { a. strongly agree } \\
\text { b. agree } \\
\text { c. doubt } \\
\text { d. disagree } \\
\text { e. strongly } \\
\text { disagree }\end{array}$ & $\begin{array}{l}16 \\
28 \\
0 \\
0 \\
0\end{array}$ & $\begin{array}{l}36.4 \% \\
63.6 \% \\
0 \% \\
0 \% \\
0 \%\end{array}$ \\
\hline 11. & $\begin{array}{l}\text { Pronunciation } \\
\text { needs to be learnt } \\
\text { and practiced to } \\
\text { encourage } \\
\text { speaking ability. }\end{array}$ & $\begin{array}{l}\text { a. strongly agree } \\
\text { b. agree } \\
\text { c. doubt } \\
\text { d. disagree } \\
\text { e. strongly } \\
\text { disagree }\end{array}$ & $\begin{array}{l}16 \\
28 \\
0 \\
0 \\
0\end{array}$ & $\begin{array}{l}36.4 \% \\
63.6 \% \\
0 \% \\
0 \% \\
0 \%\end{array}$ \\
\hline 12. & $\begin{array}{l}\text { I need to learn } \\
\text { English grammar } \\
\text { when I want to } \\
\text { have good } \\
\text { speaking skill }\end{array}$ & $\begin{array}{l}\text { a. strongly agree } \\
\text { b. agree } \\
\text { c. doubt } \\
\text { d. disagree } \\
\text { e. strongly } \\
\text { disagree }\end{array}$ & $\begin{array}{l}13 \\
31 \\
0 \\
0 \\
0\end{array}$ & $\begin{array}{l}29.5 \% \\
70.5 \% \\
0 \% \\
0 \% \\
0 \%\end{array}$ \\
\hline 13. & $\begin{array}{l}\text { Native speakers' } \\
\text { dialog is helpful } \\
\text { as a } \\
\text { model/example } \\
\text { when learning } \\
\text { speaking }\end{array}$ & $\begin{array}{l}\text { a. strongly agree } \\
\text { b. agree } \\
\text { c. doubt } \\
\text { d. disagree } \\
\text { e. strongly } \\
\text { disagree }\end{array}$ & $\begin{array}{l}5 \\
38 \\
1 \\
0 \\
0\end{array}$ & $\begin{array}{l}11.4 \% \\
86.4 \% \\
2.3 \% \\
0 \% \\
0 \%\end{array}$ \\
\hline
\end{tabular}


Learning speaking correctly and fluently need to be practiced and most of the students strongly agreed (56.8\%) and agreed $(43.2 \%)$ practice was important. Among the four aspects of language, the students thought that speaking was the most important skill for them, $40.9 \%$ strongly agreed and $59 \%$ of the students agreed. The students also perceived that learning vocabulary which were related to nursing areas help them in vocabulary mastery, $36.4 \%$ of the students strongly agreed and the rest of them also agreed (63.6\%). In learning speaking, the students strongly agreed (36.4\%) that learning language expression related with nurse's job helped them to enhance their speaking ability and the rest of the students (63.6\%) also agreed. Learning speaking could not be separated with pronunciation practice, all of the students were either strongly agreed $(36.4 \%)$ or agreed $(63.6 \%)$ that pronunciation needed to be learnt and practiced to encourage speaking ability. The students either strongly agreed $(29.5 \%)$ or agreed $(70.5 \%)$ that they need to learn grammar in order to have good speaking skill. In addition, most of the students strongly agreed $(11.4 \%)$ and agreed $(86.4 \%)$ that the sample dialog by the native speakers was helpful as a model or example when learning speaking. There were only one student $(2.3 \%)$ doubted it.

In general, the result above shows that learning speaking needs more practices. As nursing students, the ability in speaking is mostly needed to support either their academic affairs or nurse's job in the future. The language skills and components needed in speaking competence are vocabulary, language expression, pronunciation, and grammar.
The components should be practiced in order to enhance the students' speaking skill.

4.4. Finding in Need Analysis

In English subject syllabus, the objectives of English subject in Nursing Program mainly focuses on enhancing speaking ability of the students. The speaking ability is aimed at doing conversation, writing a report on nursing education, listening comprehension, and also presentation or seminar. From the result of interview with the lecturer and the student from Nursing Program which was combined with the result of the questionnaire it can be assumed that there was appropriateness between the interview and the result of questionnaire. In the interview, the lecturer said that the main focus of English subject in Nursing Program is enhancing speaking ability of the nursing students. So, in the classroom, speaking practices such as conversation, seminar, discussion, and debate were the main focus of the lesson. Whereas from the interview with the nursing student, she also claimed that actually the students need more practices in speaking because they only have opportunity to speak English only in English class which was held once a week during the semester. They were too busy with other subjects. So, their ability in speaking English still needs to be improved. Some of the students were lack of confidence when they speak with others in English. Besides, the nursing students still need more practices related with pronunciation, vocabulary, grammar, and listening comprehension that actually those components of language should be integrated to support speaking skill. Those components are appropriate with 
the micro skills of speaking by Brown (2000) and Goh \& Burns (2012).

The nursing students have hectic schedule for the subjects that they should complete in each semester in their study in a three-year diploma program in nursing. English is not their main course, there are still other subjects which are the main course in Nursing Program. In other words, English is not their priority, but they need to able to communicate using English language either for academic affairs or their professionalism. Since the nursing students only got English lesson once a week during the semester and they need more chance to practice, they need a kind of learning media which: a) can be accessed anytime and anywhere, b) portable, c) easy of use, d) support for practicing speaking, and e) support for group discussion. So, whenever the students have chance even though the chance was very limited, they can still keep in touch with English material that support for practicing speaking skill. They need a learning media which supports their needs. Active English in Nursing (AFORN), therefore, will facilitate the fulfillment of the nursing students' need.

\section{CONCLUSION}

In this part, the researcher would like to sum up the result of the study which has been discussed in the previous chapter. Since the students took a Diploma Program, the students were busy with their activity in Nursing Program to complete their study. They had tight schedule for every subject that they must fulfill in during three years. English class was only held once a week in two semesters only. In the other hand, they are demanded to be able to speak English in fluent as stated in the syllabus and the vision of Polkesyo as well to go international. Speaking skill is also important to support theis academic and professionalism. The students need a learning media which is equitable, easy of use, and flexible is something they need to get in touch with English speaking materials. The students will be possibly to access the learning media simply. It enables the nursing students to learn English whenever and wherever they are.They can learn or practice their speaking skill such as practicing the correct pronunciation, learning some various language expressions, improving vocabularies by doing exercise and also practicing listening by using a mobile learning media that was a kind of digital learning media that was installed in their smartphones. This is a kind of learning media which is capable to help them to always get the access to English at anytime and anywhere.

\section{REFERENCES}

AbuSa'aLeek, Atef Odeh. (2014). A Review of Emerging Technologies: Mobile Assisted Language Learning (MALL). Asian Journal of Education and e-Learning, Vol 02, Issue 06, December 2014. Retrieved from https://www.academia.edu/Document s/in/Mobile_Assisted_Language_Lear ning. Accessed on January 19, 2015.

Al-Rahmi, Waleed Mugahe \& Mohd Sahizan Othman. (2013). Evaluating Student's Satisfaction of Using Social Media Through Collaborative Learning In Higher Education. International Journal of Advances in 
Engineering \& Technology, Vol. 6, Issue 4, pp. 1541-1551. Retrieved from http://citeseerx.ist.psu.edu/viewdoc/d ownload?doi=10.1.1.669.5864\&rep=r ep1\&type=pdf. Accessed on February $2,2020$.

Bonwell, C. \& Eison, J. (1991). Active Learning: Creating Excitement in The Classroom (ASHE-ERIC Higher Education Report No. 1). Washington, DC: George Washington University. Abstract online at http://www.ed.gov/databases/ERIC Digest/ed340272.html. Accessed on November 4, 2014.

Borg, W.R. \& Gall, M.D. (1983). Educational Research: An Introduction. New York: Longman, Inc.

Borg, W.R. \& Gall, M.D. (2003). Educational Research: An Introduction. New York: Longman, Inc.

Brown, H. Douglas. 2000. Teaching by Principles: An Interactive Approach to Language Pedagogy. $2^{\text {nd }}$ edition. London: Longman.

Creswell, John W. (2012). Educational Research (4 ${ }^{\text {th }}$ ed.). Boston: Pearson Education, Inc.

Dudley-Evans, T \& St. John, M.J. (1998). Developments in English for Specific Purposes. Cambridge: Cambridge University Press.

Elias, Tanya. (2011). Universal Instructional Design Principles for
Mobile Learning, (IRRODL) International Review of Research in Open and Distance Learning, Vol. 12.2, February 2011.

Ellis, Rod. (2008). The Study of Second Language Acquisition. Oxford: Oxford University Press

Eison, Jim. (2010). Using Active Learning Instructional Strategies to Create Excitement and Enhance Learning. Department of Adult, Career \& Higher Education. Florida: University of South Florida. Retrieved from www.cte.cornell.edu/documents/prese ntations/Eisen-Handout.pdf on November 4, 2014.

Fauza, Hayatun, Bustami Usman \& Asnawi Muslem (2018). Improving Students'Speaking Skill And Motivation By Using Hand Puppets Show Media. English Education Journal (EEJ), 9(2), 1-18. Retrieved from

http://www.jurnal.unsyiah.ac.id/EEJ/a rticle/view/11529/9260. Accessed on March 1, 2020.

Miangah, Tayebeh Mosavi \& Nezarat, Amin. (2012). Mobile-Assisted Language Learning. IJDPS, 3(1), 309219.

http://airccse.org/journal/ijdps/papers/ 0112ijdps26.pdf

Paltridge, Brian \& Starfield Sue. (2013). The Handbook of English for Specific Purposes. Boston: Wiley Blackwell. 
Prabowo, Tri. (2015). Syllabus document of Nursing Program. Jurusan Keperawatan, Poltekkes Kemenkes Yogyakarta.

Richards, Jack C. (2006). Communicative Language Teaching Today. NY: Cambridge University Press.

Richard, Jack C. \& Renandya, Willy A. (2002). Methodology in Language Teaching (An Anthology of Current Practice). New York. Cambridge University Press.

Viberg, Olga \& Gronlund, Ake. n.d. Mobile Assisted Language Learning: A Literature Review. Retrieved from https://www.academia.edu/Document s/in/Mobile_Assisted_Language_Lear ning. Accessed on January 19, 2015 
Vol. 7 No.I April 2020

e-ISSN : 2406 - 9809 p-ISSN : 2527 - 8835

http://ejournal.upbatam.ac.id/index.php/basis

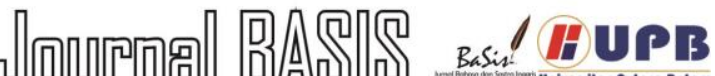

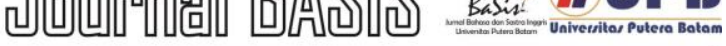

